Isabelle Marthot-Santaniello

\title{
An Important Family in Sixth-Century Hermopolis: New Insights from the Basel Papyrus Collection*
}

In 1989, Pieter J. Sijpesteijn published an article entitled “An Important Family in VI ${ }^{\text {th }}$ Century Hermupolis" describing a family archive in the British Library collection, that of Flavius Silbanos son of Phoibammōn, soldier in Hermopolis, and his son Flavius Geōrgios. ${ }^{1}$ Sijpesteijn had spotted four texts related to Silbanos and five concerning his son. He managed to reconstruct some key elements of their lives and offered a stemma of the family. ${ }^{2}$ During the $20^{\text {th }}$ International Congress of Papyrology, James Keenan showed how this documentation completes the picture of soldiers acting as "moderate landowners" and businessmen in the Hermopolite nome in the fifth and sixth centuries. ${ }^{3}$ The most recent contribution on this documentation is from Nico Kruit, who added two more papyri to this archive, one concerning Silbanos and the other Geōrgios, while studying "sales of wine for future delivery" documents. ${ }^{4}$

Until now, all the papyri forming this archive were in the British Library collection, most of them purchased in $1901 .{ }^{5}$ Among the papyri belonging to the University of Basel, acquired in the winter $1899-1900,{ }^{6}$ the small fragment P.Bas. inv. 42 bears on the verso the name "Silbanos son of Phoibammōn." It could be joined with P.Lond. III 1013 descr., a lease published in 1986 as SB XVIII 13584 that had not yet been identified as part of this archive. ${ }^{7}$ The (re-)edition of the whole text will be included in the forthcoming second volume of the Basel papyri as P.Bas. II 53.

\footnotetext{
* This article was written under the auspices of the research project 162963: "Change and Continuities from a Christian to a Muslim Society - Egyptian Society and Economy in the 6th to 8th Centuries," funded by the Swiss National Science Foundation SNSF.

1 Sijpesteijn (1989) 381-383.

2 Silbanos: P.Lond. III 992, 999 (later united with 998 = SB XVI 12488), 1051, 1316b (= SB XX 14457); Geōrgios: P.Lond. III 1000, 1001, 1020, P.Lond. V 1766 and 1872. For a discussion on the date of these texts, see below.

3 Keenan (1994) 449-450 and n. 46 adding one datum to Sijpesteijn's stemma. See fig. 1 in this chapter for an updated stemma.

4 Kruit (1994) 83 n. 65 identified Silbanos in P.Lond. III 1052a (= SB XX 14465) and Geōrgios in P.Lond. III $997=S B$ XXII 15597. An updated list of texts is given in the appendix at the end of this article. 5 The papyri from this archive which are described or published in P.Lond. III belong to a lot acquired by the British Museum from the Reverend Chauncey Murch which comprised Papyri 8841178. I am thankful to Peter Toth for this information. P.Lond. V 1766 and 1872 descr. were purchased in 1906.

6 See the forthcoming introduction of P.Bas. II by S. Huebner.

7 Parássoglou (1986). Nikolaos Gonis had also noticed the affiliation of this text with Silbanos' archive.
} 
It rounds out our knowledge of this family and its business activities, specifically in relation to transactions between family members. More pieces of the archive are very likely to be identified among the London papyri: P.Lond. III 1021 descr. p. LIII, described as a "short account presented by Silvanus son of Phoebammon, for the tenth indiction" refers to "our" Silbanos and has just been published. ${ }^{8}$ P.Lond. III 1053 descr., also due to be published in the near future, ${ }^{9}$ has been identified as the end of SB XVI 12488, which had previously been spotted as part of Silbanos' archive. Extensive work on the London collection to reconstruct this archive will surely bring more texts to light, but this task is, however, beyond the scope of the present paper, which aims to sum up the currently available data from the archive to show how Silbanos kept closely in touch with the sons that helped him to run his multifaceted business.

When Silbanos first appears in our documentation, he is already a soldier in the unit (arithmos, the equivalent of numerus) of the Mauri in Hermopolis. ${ }^{10}$ The oldest securely dated text from this archive is a famous compromissum, P.Lond. III 992 (507), ${ }^{11}$ which gives important information about his family: it deals with a dispute Silbanos and his brothers had with their sister. One of his brothers, Sarapiōn, is also a Flavius and serves as a soldier in the same numerus. Another, named Isakos, is an Aurelius and represents the heirs of the late third brother, Tyrannos. The opposite party is formed by the sister, named Aurelia Archontia, and her husband Flavius Bēsnikōn, another soldier in the same unit. It is expressly stated that they are all from Hermopolis. We do not know much about the object of the dispute. Keenan has described the compromissum as follows: "Its participants agree to abide by an arbitration ruling to be made by two scholastici of the forum of the Thebaid in a division of family property. Significant, of course, is that the family had property to divide (though details are not given)." 12 In fact, the text does not mention real property but states that the dispute is "about certain capital sums."13 The parties involved, i.e. all the brothers on one side and the married sister on the other, may be an indication that the dispute was about the paternal inheritance. Phoibammōn's belongings may first have been (or were intended to be) left undivided among his five children (and their heirs) and managed by the elder brother. Whether Aurelia Archontia was already married at the time of her father's death or married later, she could have de-

8 Gonis (2019) 237-241. I am thankful to the author for a preview. In his note 24 on page 241, Niko-

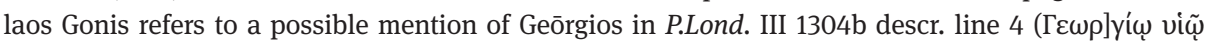
$\Sigma \iota \lambda \beta \alpha v o \tilde{)})$, a legal agreement of 566/567. A future edition may ascertain the belonging of this text to the archive.

9 The publication will be part of my study on the notary Mēnas' dossier.

10 For the most recently published text (probably) concerning this unit, see P.Gascou 21.4-5 (Hermopolis (?), 514) and the bibliography gathered in the note p. 61-62, with explicit reference to Silbanos' archive.

11 Reprinted in Chrest.Mitt. 365; Sel.Pap. I 61 and FIRA III 182.

12 Keenan (1994) 449.

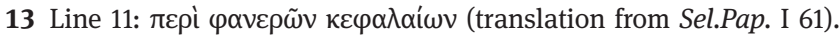


sired - or been pressured - to separate her share from her brothers' so that her husband could manage it. ${ }^{14}$ The modalities of the division would have generated the family dispute, with the possible existence of a dowry as an additional complicating factor. ${ }^{15}$ Nevertheless, this text shows that Silbanos came from a Hermopolite family that was already of some means. No other text mentions Silbanos' brothers and sister or his brother-in-law. ${ }^{16}$

We are currently aware of only two other documents that refer to Silbanos during his time as an active soldier. P.Lond. III 1021 is an account where Silbanos appears in the heading with his sons and associated with an optio. It is drawn in the eleventh indiction for the surplus of the tenth. Nikolaos Gonis has argued on monetary and prosopographical reasons that the eleventh indiction corresponds more likely to 502/503, thus making this text the oldest of the archive, although 517/518 cannot be excluded. ${ }^{17}$ The second text is $S B \mathrm{XX} 14465$, a list registering amounts of money and labeled "of the soldier Silbanos." It is unclear whether the sums mentioned were paid or received by Silbanos. The only hint comes in line 5, where the amount is apparently for a garment, which would point to the document being a list of expenses. ${ }^{18}$ The seven entries for which the day of the month is indicated, lines 4 to 10, were all made within less than 30 days, from 18 Thōth to 13 Phaōphi, and they come to a total of 24,400 talents. ${ }^{19}$ This suggests that Silbanos was already running some kind of business or had substantial sums that he could spend or invest on various transactions. SB XX 14465 has been of interest to scholars since it may show how talents could be converted to solidi (even if the editor princeps doubted this), but otherwise it does not contain elements which could date it firmly. Jean Gascou has dem-

14 Huebner (2014) 102 on evidence from Roman Egypt: "Sisters in Roman Egypt usually joined their brothers in their efforts to keep the paternal estate undivided. However, if the sister was already married and lived elsewhere, some division of property became necessary."

15 Huebner (2014) 104: "Dowries were unknown in Egypt in Pharaonic times [...]. However, in Hellenistic times the practice of endowing a daughter became more widespread in Egypt also. In Roman Egypt, we then find a combination of practices: daughters usually received a dowry but also held a right to a share in the parental inheritance, including houses and land. Dowries and inheritances complemented each other: the value of the dowry, consisting mainly of female goods, was subtracted from the later share in the parental property."

16 A Fl. Isakos son of Phoibammōn is a witness in P.Lond. III 1001 concerning Geōrgios. Sijpesteijn, in his article from 1989, p. 382 n. 8, says that he may be the same person as Silbanos' brother, without addressing the question of the change of status designation between Flavius and Aurelius. Kruit, in his article from 1994, p. 83 n. 65, seems to accept the idea that this Isakos is Geōrgios' uncle, but he rejected his identification with the contractor in P.Stras. V 493, 10, as suggested by the editor of the Strasbourg papyrus.

17 Gonis (2019) 237 and 241 (discussion on the dating).

18 The editor reads an erroneous form of cheiridion, usually "a glove for rubbing the body" but also maybe a diminutive of cheiris, "a loose sleeve as worn by Persians, Gauls, and tragedians"; see P.Mich. XV 752.42n.

19 For comparison, the delivery of two suckling-pigs, one worth 6,000 talents and the other 5,000, is included in the rent agreement SB IV 7369.17 and 26 (Hermopolis; 512). 
onstrated that the last attestation of the Mauri as being active is from 528 and that they had already been replaced by the Numides by 533/534 at the latest; that provides us with a terminus ante quem for this text. ${ }^{20}$ We do not know when Silbanos started his soldierly career. It could have been a couple of years before the compromissum, and thus this list could theoretically have been written before 507. Constantin Zuckerman even suggested dating it to before 504 for monetary reasons. ${ }^{21}$ However, according to Kruit, "the handwriting of this papyrus looks identical to that of P.Lond. III 1316b," a text whose writer happens to be known from another document. ${ }^{22}$

P.Lond. III 1316b, now SB XX 14457, is indeed a receipt delivered by Silbanos, "former soldier," and expressly written by his son Petros because Silbanos "does not know the letters." 23 It acknowledges the payment in money of a rent for the crops of a fifth indiction by Biktōr, a farmer from the village of Senilais. P.Lond. III 1051 is a similar receipt, issued by Silbanos to Biktōr for the crops of a twelfth indiction, for a slightly higher amount. ${ }^{24}$ This time, Silbanos signed himself, in a very illiterate hand. There is no mention of whether he is still an active soldier or already a veteran. Dating these two texts thus depends on evidence from the other texts in the archive and its interpretation.

Thanks to preserved consular dates in three documents, some key elements of Silbanos' life can be established firmly: in SB XVI 12488.4-5, from December 538, Silbanos, while making an advance payment for wine to a deacon (diakonos) of the village of Enseu, ${ }^{25}$ is designated as a "former soldier of the numerus of the Mauri that used to be in Hermopolis." P.Lond. V 1766, from January 559, refers to Geōrgios as being "the son of the late Silbanos," whereas in P.Lond. V 1872 from November 548, he is just said to be "the son of Silbanos." Therefore, Silbanos must have died some time between the end of 548 and the beginning of 559 .

Relying on the fact that Silbanos retired from active service in 538 and died at the latest in 559, Sijpesteijn argued that $S B$ XX 14457, the receipt from a fifth indiction where Silbanos is said to be a "former soldier" who "does not know the letters" must be dated to 541/542 or 556/557. Sijpesteijn then assumed that the other receipt, P.Lond. III 1051 from the twelfth indiction, signed by Silbanos with a hesitant hand, is posterior since "Silvanus seems at least to have learned to sign the receipts he issues." ${ }^{26}$ He thus excludes the possibility of dating it to 534 but dates it to 549 without

20 Gascou (2008) 314-315.

21 Zuckerman (2004) 61 n. 18: Observing that a solidus minus 4 carats is equivalent to 23,400 talents, and that in SB XVI 12378 (504) and CPR VII 43 (513) the solidus is already minus 5 carats, Zuckerman suggests $S B$ XX 14465 predates these two texts.

22 Kruit (1994) 83 n. 65.

$23 S B$ XX 14457.7-9.

24 SB XX 14457.5: 17 carats; P.Lond. III 1051.4-5: one solidus minus 6 1/4 carats $=17$ 3/4 carats.

25 For deacons' activities without obvious links to the Church a century later, see Anne Boud'hors's contribution to this volume, Section 2.2 and n. 17.

26 Sijpesteijn (1989) 382. 
coming back to his previous alternative date for $S B$ XX 14457, 556/557, which would not match his logic anymore.

The text that has been pieced back together again through the link made between the London and Basel collections adds a new element to this discussion: it is dated to a second indiction, and to a consular year which corresponds to October 538. It is thus anterior to $S B$ XX 14457 (from a fifth indiction) but bears Silbanos' subscription, as broad and clumsy as in P.Lond. III 1051. This proves that Silbanos would have been able to sign the rent receipt SB XX 14457 but, probably for convenience, asked his son Petros to subscribe for him. This is an interesting case of semi-literacy which complements the well-known case of Petaus, the scribe who could not write, and other similar cases. ${ }^{27}$ It reminds us not to take assessments that a certain person "does not know the letters" too literally; in some cases, like that of Silbanos, a person apparently $\mathrm{did}^{28}$ but preferred to delegate tasks to more skilled writers. ${ }^{29}$ Now that P.Lond. III 1051 does not have to be posterior to SB XX 14457 anymore, the possibility of dating it to 534 can no longer be excluded.

P.Bas. II 53 is interesting not only because it bears Silbanos' signature and can be dated, but also because it shows the former soldier leasing land from his own son, Petros. Furthermore, the land is said to be owned in common with Petros' two other brothers, the well-known Geōrgios and the as-yet unknown Phoibammōn. The latter thus bears, as was often the case, the same name as his paternal grand-father, which may indicate that he was the first-born male child. ${ }^{30}$ The provenance of the leased land is lost in the lacuna, but it is tempting to think of a maternal inheritance shared

27 Youtie (1973) 677; Kraus (2000) 334-338; for a recent overview of literacy in Roman Egypt, see Huebner (2018) 164-166.

28 Kraus (2000) 325-328 and 340 distinguishes between formulas expressing that a person "does not know the letters" (type A), "is illiterate” (type B), or is a "slow writer" (type C), but he never considers the possibility that these expressions may not reflect reality, nor comments on the fact that type C seems to disappear after the fourth century. For a more nuanced view, see Wipszycka (1996) 115 n. 10: "Il n'est cependant pas toujours certain que ceux qui ne signent pas un document, mais autorisent quelqu'un d'autre à le faire pour eux, soient des analphabètes” and the case of Athanasios from eighth-century Jeme who uses an hypographeus although he could write with elegance. Wipszycka (1996) 132 about a doctor (iatros) qualified to be "illiterate" (agrammatos): "Dans le cas de ce médecin qui est dit áypá $\mu \mu \alpha \tau o \varsigma$, de même que dans d'autres cas similaires, je soupçonne qu'il peut s'agir, non pas d'un analphabète, mais d'une personne qui n'est pas en mesure d'écrire dans la situation donnée. [...] Il est vrai qu'on s'attendrait à trouver, dans des cas pareils [circumstantial inca-

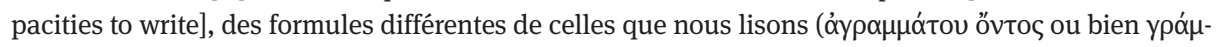

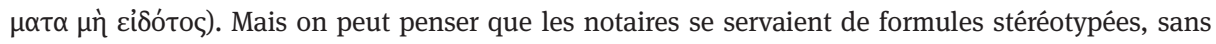
chercher à les adapter à la situation concrète. Certainement il vaudrait la peine d'étudier, dans l'ensemble des documents grecs d'Égypte, pour toutes les époques, tous les cas où ces formules traditionnelles paraissent suspectes.”

29 Kraus (2000) 326-328 on the importance of the hypographeus, the person writing on behalf of others.

30 Delattre (2014) 155: "le premier enfant mâle porte traditionnellement le nom de son grand-père paternel." 
between the three children. Since it is explicitly itself a quarter of a previous lot, a further hypothesis would be that the mother had herself equally shared a parental inheritance with three siblings. ${ }^{31}$ The properties leased by Petros to his father are scattered in three different locations in the territory of Enseu. Hence, this new text provides background to $S B$ XVI 12488, drawn up only two months later: while taking care of Petros' land in Enseu, Silbanos established the connexions he needed to invest some of his money in an advance sale of wine in the same village. Besides, the join between SB XVI 12488 and P.Lond. III 1053 descr. shows that the contract of sale was written by Mēnas, the same notary who wrote P.Bas. II 53, another connection that probably eased the drafting of the contract. Another text played a part in the genesis of SB XVI 12488: Nico Kruit showed that SB XXII 15597 from October 537, which is also a sale of wine for future delivery, but this time with Geōrgios as the purchaser, was subsequently used as a model by Silbanos for his own similar contract. The names of the notary and the village are lost, but some technical clauses, not found in any other document, prove the close business collaboration that Silbanos had with his son Geōrgios.

What kind of relationship did Silbanos have with his other sons? Phoibammōn is not attested elsewhere but, regarding Petros, it has already been mentioned that he helped his father run his business by writing at least one rent receipt and a money account for him. But if Silbanos had a good relationship with Petros, why would he have needed to draw up a contract with his own son to cultivate his land? There are still lacunas in the lease, but it does indeed contain specific clauses that make it unusually favorable for the lessee, i.e. Silbanos. The lease is for as long as the lessee, not the lessor, desires. Petros seems to temporarily waive his ownership and complete lawful possession of his share of the land in favor of his father (for example, he cannot decide to sell the land while it is leased out) and there is an unparalleled wording stating that all income (pantoias prosodou) from the land will go to Silbanos. These specificities suggest that thanks to this lease, Silbanos could use this land almost as freely as if he owned it. If the land was indeed first owned by Silbanos' wife, Silbanos, as the husband, was likely to have managed it. Through this contract, he is assured to be able to continue in the future, at least as far as Petros' share is concerned.

Was this a specific arrangement Silbanos made only with Petros, or were there two similar contracts through which Silbanos also leased the shares of his two other sons? It is not possible to give a definitive answer to this question, but one could argue that if one or both of the other sons had agreed similar terms, the simpler solution would have been to draw up only one contract mentioning several les-

31 This hypothesis does not consider a possible reduction of her share resulting from the deduction of a previous dowry, see n. 19 above. For an example of an equal share between two brothers and a sister, even if the sister has a child, see Huebner (2014) 106-107. 
sors. Nothing is known about Phoibammōn, but Geōrgios was already an active businessman in his own right by that time.

Keenan pointed out that Geōrgios probably inherited his father's papers. ${ }^{32}$ As already seen, the similarity between the two advance sales of wine showed that he had a close business relationship with Silbanos in the years 537-538. In November 538, he wrote P.Lond. III 1000, the draft of a petition to an official requesting the enforcement of the payment of a debt he had failed to recover. P.Lond. III 1001, from February 539, is an advance purchase agreement for wheat and wine that he contracted with a winemaker, once again in Enseu. In most of the texts that relate to him, Geōrgios is called Flavius, ${ }^{33}$ but, in this text only, he is referred to as "Flavius Geōrgios, son of Silbanos, former soldier from Hermopolis." Keenan simply mentions that Geōrgios was "also a soldier," 34 but Kruit closely examines this point. After admitting that Geōrgios could have been a veteran of the Mauri, like his father, or have served in the unit of the Numides which replaced them, he underlined that Geōrgios' military status should show up in more than one text and does not fit with the honorific title thaumasiotatos used twice about him. ${ }^{35}$ He rejected Sijpesteijn's idea that the "former soldier" referred to Silbanos and not Geōrgios on the ground that "it would be unnatural to read the address of P.Lond. III 1001 in this way." 36 He sums up the discussion by saying that he does not think that any conclusion can be reached. ${ }^{37}$ It seems, however, more likely that if Geōrgios had been a soldier, he would have mentioned it in more documents, and especially in the draft of petition P.Lond. III 1000. Taking the whole archive into consideration, it is more plausible that Geōrgios was a young businessman rather than already a veteran in 539, since his activities are still documented twenty years later. ${ }^{38}$

After a gap of almost ten years, in 548, Geōrgios reappears in the documentation as the owner of a house which he rents to a villager from Nagōgis in P.Lond. V 1872 descr. With another inhabitant of this same village, Geōrgios subsequently draws up P.Lond. V 1766 in 559, an agreement on payment of arrears for the rent of his property. ${ }^{39}$ A final text, P.Lond. III 1020 (p. 272) is from a fifth indiction, but evidence that could determine the precise year concerned is lacking. The text depicts Silbanos' son as "brother Geōrgios" receiving an acknowledgement of rent payment from another inhabitant of Hermopolis, Basileidēs son of Phoibammōn. Sijpesteijn and Keenan,

32 Keenan (1994) 450.

33 The use of Aurelius in P.Lond. V 1872.4 is probably due to scribe confusion.

34 Keenan (1994) 450.

35 Kruit (1994) 84-85.

36 Kruit (1994) 86 n. 72.

37 Kruit (1994) 86.

38 Gonis (2019) 237 and n. 4.

39 The same lessee, Aur. Kollouthos son of Kyriakos from Nagōgis, appears in another lease, P.Lond. III 1006 (p. 260) from 555, whose lessor Aur. Petros son of Pinoutiōn from the same village is also attested in $S B$ XX 14455, a tax receipt. There is not enough evidence to suggest that these two papers had found their way into Geōrgios' archive. 
following the editor, respectively consider Geōrgios to be "the representative of Cyrilla and Maria, a nun" 40 or "acting in behalf of two nuns," 41 but the situation is rather unusual: two women named Kyrilla and Maria seem to have already passed away (makariai) and Geōrgios pays "their" rent to Basileidēs, a rent that is described as one-sixth of the two women's produce (ekphoria) in Hermopolis and in the village where they were nuns (or at least Maria was a nun). The exact relationship between all these people is not specified. Evidence is too thin to speculate that Geōrgios became a monk at the end of his life and was called "brother" for that reason. It is also unlikely that he had changed the nature of his activities from landlord to tenant, cultivating land that two nuns used to cultivate (or sub-let) before him. An interpretation that fits the general picture of Geōrgios better would be that "brother" was here merely a respectful appellation, not referring to any monastic status, and that Geōrgios was either a sub-tenant or the person in charge of managing the business and the legacy of the two women rather than the person who actually worked the land. This text thus shows another aspect of his entrepreneurial activities. ${ }^{42}$ It is possible that this text is the most recent one, and the fifth indiction could then correspond to $571 / 572$, but 541/542 or 556/557 cannot be excluded.

What about the next generation? It has been mentioned that the last firmly dated texts referring to Geōrgios illustrate his activities as the landlord of a house and a property in Nagōgis. Another Basel papyrus also makes reference to this same village: in P.Bas. II $66,{ }^{43}$ a villager rents irrigation equipment from a Hermopolite resident, Phoibammōn son of the blessed Georgiōs, whom it is tempting to see as Silbanos' grandson. An Aurelius bearing this name and patronymic is attested in two leases from P.Lond. III dated from 576 and 583; this would nicely add a more recent chapter to the family chronology, but at the moment, this is still mere speculation..$^{44}$

In conclusion, this archive of a dozen texts yields very little information on Silbanos' life as a soldier but sheds rather more light on his family and on his business affairs. This is consistent with Keenan's conclusion that "the Mauri do at any rate seem to have been citizen soldiers, leading, like the soldiers of the Patermuthis archive, active family lives; full-time professional soldiering may only have come to Hermopolis with the introduction of the Numidae Iustiniani in the mid-sixth century." ${ }^{45}$ Silbanos, at least, leased out land and bought wine in advance. His son Geōr-

40 Sijpesteijn (1989) 382.

41 Keenan (1994) 450.

42 I am grateful to Joanna Wegner for discussing the possible interpretations of this document with me.

43 Forthcoming reedition of P.Bas.Copt. I 1 (SB Kopt. IV 1805).

44 P.Lond. III 1326a = SB XVI 12865 (576) and P.Lond. III 1326b = SB XVI 12866.4-5 (583). The second text fits well with P.Bas II 66. Phoibammōn is the tenant (and is said to be geōrgos) in the first text but the landlord is a comes, so it could be a case of subleasing. The Hermopolite origo is restored in the lacuna.

45 Keenan (1994) 451. 
gios is attested in more various activities: besides agricultural leasing, he also granted loans of money, leased out a house and bought wheat as well as wine in advance from producers. The collaboration between Silbanos and his sons was probably a key factor in creating this prosperity.

\section{Bibliography}

FIRA $=$ Fontes iuris Romani antejustiniani $\left(2^{\text {nd }}\right.$ ed. $)$

Delattre (2014): Alain Delattre, “Éléments de l'identification en Égypte (IVe-VIII' siècles)", in: Mark Depauw and Sandra Coussement (eds.), Identifiers and Identification Methods in the Ancient World (Orientalia Lovaniensia Analecta 229), Leuven, 153-162.

Gascou (2008): Jean Gascou, Fiscalité et société en Égypte byzantine (Bilans de recherche 4), Paris.

Gonis (2019): Nikolaos Gonis, "Soldiers and money in early sixth-century Hermopolis", in: Zeitschrift für Papyrologie und Epigraphik 209, 237-241.

Huebner (2014): Sabine R. Huebner, "'It is a difficult matter to be wronged by strangers, but to be wronged by kin is worst of all.' Inheritance and conflict in Greco-Roman Egypt" in: Béatrice Caseau and Sabine Huebner (eds.), Inheritance, Law and Religions in the Ancient and Mediaeval Worlds (Monographies du Centre de recherche d'Histoire et Civilisation de Byzance 45), Paris, 99-108.

Huebner (2018): Sabine R. Huebner, "Frauen und Schriftlichkeit im römischen Ägypten”, in: Anne Kolb (ed.), Literacy in Ancient Everyday Life. Schriftlichkeit im antiken Alltag, Berlin, 163-178.

Keenan (1994): James G. Keenan, "Soldier and civilian in Byzantine Hermopolis", in: Adam Bülow-Jacobsen (ed.), Proceedings of the $20^{\text {th }}$ International Congress of Papyrologists, Copenhagen, 23-29 August 1992, Copenhagen, 444-451.

Kraus (2000): Thomas J. Kraus, “(II)literacy in non-literary papyri from Greco-Roman Egypt. Further aspects of the educational ideal in ancient literary sources and modern times", in: Mnemosyne 53, 322-342.

Kruit (1994): Nico Kruit, “Three Byzantine sales for future delivery. $S B$ XVI $12401+12402, S B$ VI 9051, P.Lond. III 997", in: Tyche 9, 67-88.

Parássoglou (1986): George M. Parássoglou, “Byzantina misthoteria ges”, in: Hellenika 37, 72-77.

Sijpesteijn (1989): Pieter J. Sijpesteijn, “An important family in $\mathrm{VI}^{\text {th }}$ century Hermupolis", in: Hellenika 40, 381-383.

Wipszycka (1996): Ewa Wipszycka, Études sur le christianisme dans l'Égypte de l'antiquité tardive (Studia Ephemeridis “Augustinianum” 52), Roma.

Youtie (1973): Herbert C. Youtie, “Pétaus, fils de Pétaus, ou le scribe qui ne savait pas écrire”, in: Scriptiunculae II, 677-693.

Zuckerman (2004): Constantin Zuckerman, Du village à l'Empire. Autour du registre fiscal d'Aphroditô (525/526) (Monographies du Centre de recherche d'Histoire et Civilisation de Byzance 16), Paris. 


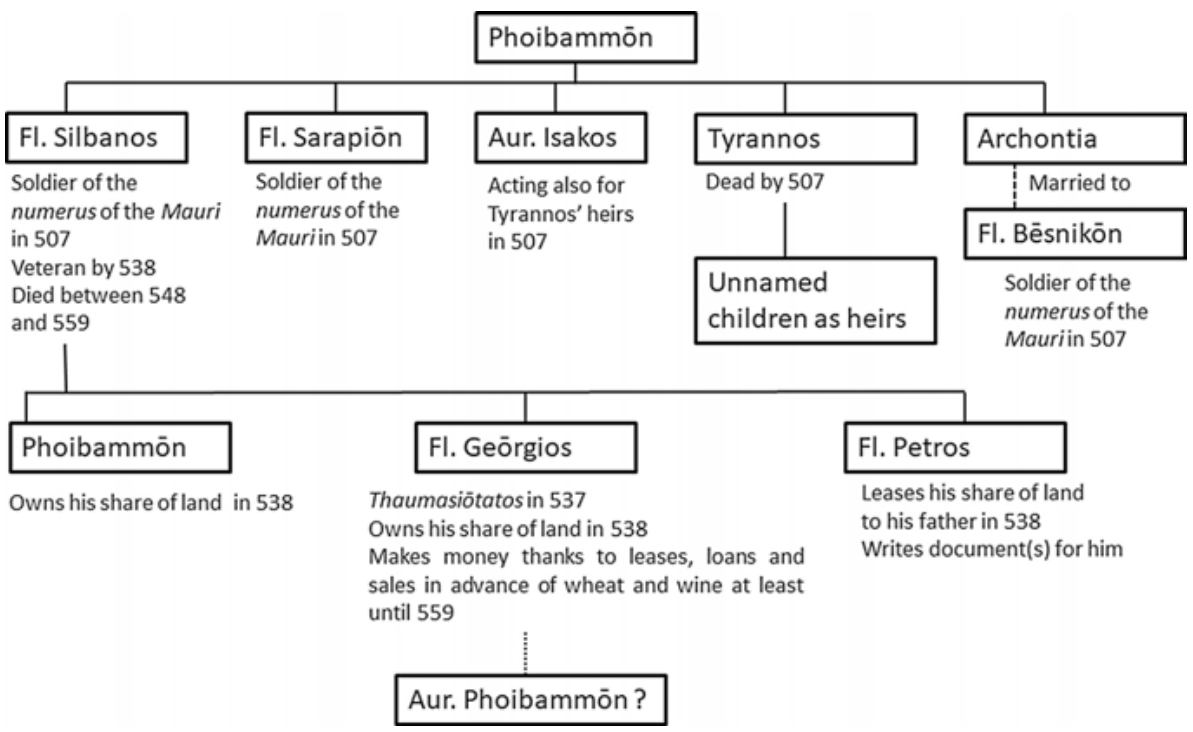

Fig. 1: Family tree of Phoibammōn

Appendix: Overview of the archive ${ }^{46}$

\begin{tabular}{lllll}
\hline Publication & Inventory & Date & Type of document & People mentioned \\
\hline Gonis (2019) & P.Lond. III & 11th & Account (money) & $\begin{array}{l}\text { Silbanos s. Phoibammōn and his } \\
\text { sons }\end{array}$ \\
& $\begin{array}{l}1021 \\
\text { descr. }\end{array}$ & $\begin{array}{l}\text { ind. 502/3 } \\
\text { (or 517/8) ? }\end{array}$ & \\
\hline
\end{tabular}

P.Lond. III 992 P.Lond. III July 507 Compromissum

(p. 253) 992

Fl. Silbanos s. Phoibammōn, soldier of the numerus of Mauri Fl. Sarapiōn, soldier in the same unit

Aur. Isakos

Tyrannos $†$

Aur. Archontia, married to Bēsni-

kōn, soldier in the same unit

\begin{tabular}{|c|c|c|c|c|}
\hline SB XX 14465 & $\begin{array}{l}\text { P.Lond. III } \\
1052 a\end{array}$ & $\begin{array}{l}507-533 / \\
534\end{array}$ & Account (money) & $\begin{array}{l}\text { Silbanos soldier } \\
\text { Hand identified as Petros' }\end{array}$ \\
\hline SB XXII 15597 & $\begin{array}{l}\text { P.Lond. III } \\
997 \\
\text { descr. }\end{array}$ & 12.10 .537 & $\begin{array}{l}\text { Sale of wine for future } \\
\text { delivery }\end{array}$ & $\begin{array}{l}\text { Fl. Geōrgios, son of Silbanos } \\
\text { Aur. Apollos s. NN and Adora, } \\
\text { wine dresser (ampelourgos) }\end{array}$ \\
\hline
\end{tabular}

46 The present appendix does not include the texts the belonging of which to the archive is doubtful. For them, see above n. 8 and 44 as well as the TM Archive 468 on trismegistos.org. 
Appendix: Overview of the archive (Continued)

\begin{tabular}{|c|c|c|c|c|}
\hline Publication & Inventory & Date & Type of document & People mentioned \\
\hline P.Bas. II 53 & $\begin{array}{l}\text { P.Bas. } 42 \\
+ \text { P.Lond. } \\
\text { III } 1013\end{array}$ & 8.10 .538 & $\begin{array}{l}\text { Lease of land in } \\
\text { Enseu }\end{array}$ & $\begin{array}{l}\text { Fl. Silbanos s. Phoibammōn } \\
\text { Fl. Petros, Phoibammōn and } \\
\text { Geōrgios, his sons. }\end{array}$ \\
\hline $\begin{array}{l}\text { P.Lond. III } \\
1000 \text { (p. 250) }\end{array}$ & $\begin{array}{l}\text { P.Lond. III } \\
1000\end{array}$ & 28.11 .538 & $\begin{array}{l}\text { Petition (libelli) to } \\
\text { some official about } \\
\text { the payment of a debt }\end{array}$ & $\begin{array}{l}\text { Fl. Geōrgios s. Silbanos from Her- } \\
\text { mopolis } \\
\text { Phibis called Patah from Hermop- } \\
\text { olis and maybe another debtor? }\end{array}$ \\
\hline $\begin{array}{l}\text { SB XVI } 12488 \\
+ \text { P.Lond. III } \\
1053 \text { (forth.) }\end{array}$ & $\begin{array}{l}\text { P.Lond. III } \\
998-999\end{array}$ & 2.12 .538 & $\begin{array}{l}\text { Advance payment of } \\
80 \text { measures of wine }\end{array}$ & $\begin{array}{l}\text { Iōannēs s. Kollouthos and Arch- } \\
\text { ontia, diakonos of the village of } \\
\text { Enseu } \\
\text { Fl. Silbanos s. Phoibammōn, ex- } \\
\text { soldier of the numerus of the } \\
\text { Mauri }\end{array}$ \\
\hline $\begin{array}{l}\text { P.Lond. III } \\
1001 \text { (р. 270) }\end{array}$ & $\begin{array}{l}\text { P.Lond. III } \\
1001\end{array}$ & 14.02 .539 & $\begin{array}{l}\text { Sale of wheat and } \\
\text { wine in advance }\end{array}$ & $\begin{array}{l}\text { Fl. Geōrgios s. Silbanos, ex-sol- } \\
\text { dier in Hermopolis } \\
\text { Aur. Kollouthos s. Lythios and } \\
\text { Tsa-, winedresser from Enseu. }\end{array}$ \\
\hline
\end{tabular}

\begin{tabular}{|c|c|c|c|c|}
\hline SB XX 14457 & $\begin{array}{l}\text { P.Lond. III } \\
1316 \mathrm{~b} \\
\text { descr. }\end{array}$ & $\begin{array}{l}\text { 5th } \\
\text { ind. } 541 / 2 \\
\text { (or } 556 / 7 \text { ) }\end{array}$ & $\begin{array}{l}\text { Receipt of rent for } 17 \\
\text { carats }\end{array}$ & $\begin{array}{l}\text { From Silbanos ex-soldier to Biktōr } \\
\text { s. Pinēs, geōrgos of Senilais; } \\
\text { written by Fl. Petros, his son. }\end{array}$ \\
\hline $\begin{array}{l}\text { P.Lond. V } \\
1872 \text { descr. }\end{array}$ & 1689 & 4.11 .548 & $\begin{array}{l}\text { Lease of house prop- } \\
\text { erty to a villager }\end{array}$ & $\begin{array}{l}\text { Aur. Geōrgios s. Silbanos from } \\
\text { Hermopolis } \\
\text { Aur. Pkylis s. Kopreous and Anna } \\
\text { from the village of Nagōgis }\end{array}$ \\
\hline $\begin{array}{l}\text { P.Lond. III } \\
1051 \text { (p. 273) }\end{array}$ & $\begin{array}{l}\text { P.Lond. III } \\
1051\end{array}$ & $\begin{array}{l}\text { Epeiph, 13th } \\
\text { ind. July } 549 \\
\text { (or 534) }\end{array}$ & $\begin{array}{l}\text { Receipt of rent in } \\
\text { money, } 1 \text { solidus } \\
\text { minus } 61 / 4 \text { carats }\end{array}$ & $\begin{array}{l}\text { From Silbanos s. Phoibammōn } \\
\text { to Biktōr s. Pinēs, geōrgos from } \\
\text { the village of Senilais. Illiterate } \\
\text { subscription from Silbanos. }\end{array}$ \\
\hline $\begin{array}{l}\text { P.Lond. V } \\
1766\end{array}$ & 1682 & 14.01 .559 & $\begin{array}{l}\text { Agreement on arrear } \\
\text { payment of rent owed } \\
\text { on a lease }\end{array}$ & $\begin{array}{l}\text { Fl. Geōrgios s. late Silbanos } \\
\text { Aur. Kollouthos s. Kyriakos from } \\
\text { Nagōgis }\end{array}$ \\
\hline $\begin{array}{l}\text { P.Lond. III } \\
1020 \text { (p. 272) }\end{array}$ & $\begin{array}{l}\text { P.Lond. III } \\
1020\end{array}$ & $\begin{array}{l}\text { 5th } \\
\text { ind. } 571 / 2 \\
\text { (or } 541 / 2 \text { or } \\
556 / 7 \text { ) }\end{array}$ & $\begin{array}{l}\text { Receipt for the rent of } \\
\text { late Kyrilla and Maria, } \\
\text { nuns }\end{array}$ & $\begin{array}{l}\text { Brother Geōrgios s. Silbanos pay- } \\
\text { ing to Basileidēs s. Phoibammōn } \\
\text { from Hermopolis }\end{array}$ \\
\hline
\end{tabular}


